\title{
Respect for Nature - A Prescription for Developing Environmental Awareness in Preschool
}

\author{
Eva ÄrLEMALM-HagSÉR ${ }^{1}$
}

$\approx$ Embedded in the notion of sustainability lies a striving for an environmentally sustainable world and respect and care for the non-human world, as well as efforts to establish social, economic and political justice for all people. This paper deals with education for sustainability in Swedish pre-schools from two perspectives: first, the views held concerning the relationship between human beings and nature; second, young children's participation and agency. The theoretical underpinning is informed by critical theory with a case study approach. The empirical material is derived from 21 applications, which were from Swedish preschools to be certified with »The Diploma of Excellence in Sustainable Development « (Swedish National Agency for Education). The main findings show that few critical questions are raised about the human-nature relationship in the applications, even though views concerning the connectedness with, and care and respect for the natural world are emphasised. Children's participation and agency are neglected in a structure of ready-made views, activities and working methods already imbedded in the current pedagogical practices. Implications for research and practice would be to further explore how the understandings of the relationship between humans and nature are constructed within early childhood education.

Keywords: Early childhood education, Education for sustainability, Environmental ethics, Critical theory

1 Department of Education, Communication and Learning, University of Gothenburg, P.O. Box 300, SE-405 30 Gothenburg, Sweden eva.arlemalm-hagser@ped.gu.se 


\section{Spoštovanje narave - pristop, ki lahko uspešno razvija naravovarstveno zavedanje otrok $\mathrm{v}$ predšolskem obdobju}

Eva ÄrLEMAlM-HagsÉr

$\propto$ Trajnost navadno povezujemo s prizadevanji za okoljskotrajnostni svet in spoštovanje ter s skrbjo za življenjska okolja pa tudi s trudom za oblikovanje socialno, gospodarsko in politično pravičnega sveta za vse ljudi. V prispevku je predstavljeno izobraževanje za trajnostni razvoj, ki ga vpeljujejo v švedskih vrtcih, in sicer $\mathrm{z}$ dveh perspektiv - odnos med ljudmi in naravo ter sodelovanje in angažiranost otrok pri trajnostnem delovanju. Teoretični del zajema pregled literature trajnostnega razvoja s poudarkom na študiji primera. Podatki v empiričnem delu so bili zbrani na podlagi 21 prijav švedskih vrtcev za pridobitev certifikata »The Diploma of Excellence in Sustainable Development « [Diploma odličnosti za trajnostni razvoj] (Švedska nacionalna agencija za izobraževanje). Izsledki kažejo, da se v prijavah ne pojavlja veliko kritičnih vprašanj glede odnosa med ljudmi in naravo, čeprav so poudarjeni vidiki povezanosti ljudi z naravo ter s skrbjo in spoštovanjem do narave. Sodelovanje in angažiranost otrok sta $\mathrm{v}$ trenutnih smernicah in metodah dela $\mathrm{v}$ pedagoški praksi na predšolski stopnji zanemarjena. Podrobneje bi bilo treba raziskati, kako se razumevanje odnosa med ljudmi in naravo razvija v predšolski vzgoji in izobraževanju.

Ključne besede: predšolsko izobraževanje, izobraževanje za trajnost, okoljska etika, kritična teorija 


\section{Introduction}

It is widely agreed that education is an indispensable vehicle for improving the possibilities for a sustainable society and for enhancing sustainable lifestyles (Scott \& Gough, 2004) in which children are acknowledged as environmental stakeholders (Agenda 21) with a right to meaningful participation in environmental issues. One key element that has been recognised is the importance of promoting a potentially life-long disposition towards caring for the environment among young children and youth (Davis \& Elliott, 2003). Experiences of and interaction with nature have often been seen as a significant means for cultivating children's interest in and concern for the environment (Chawla, 1998, 1999; Ewert, Place, \& Sibthorp, 2005; Wilson, 1997). Chawla and Flanders Cushing (2007) point out that notions about how pro-environmental behaviours are fostered often falter as a result of simplistic understandings about the relationship between experiences in nature and behaviour changes and stress that these issues are inextricably linked to politics and children's ownership and involvement. In recent decades, a more participatory and critical educational approach to the modification of environmental behaviour has been observed (Barrat Hacking, Barrat, \& Scott, 2007; Chawla \& Flanders Cushing, 2007). From previously being seen as passive vulnerable recipients, children are now acknowledged as competent, resilient and active agents, citizens with the right to be involved and to be heard in matters that affect them (Davis, 2010).

Recently, arguments have been raised in favour of research with critical and philosophical perspectives. For example, there is Kopinas' (2012) request for more explicit clarification of the underlying environmental ethics, in particular in education for sustainable development and education for sustainability research. In this perspective, both the ethics of research and the ethical point of view within pedagogical practice are of interest. The relationship between humans and nature has been discussed in terms of how humans position themselves in relation to nature, and a human centred-view has been inherited from the Enlightenment of seventeenth-century Europe (Merchant, 1994). In early childhood education, the power differentials in a contemporary human-nature relationship have not been questioned to any meaningful extent (Elliott, 2008; Halldén, 2011).

In order to explain the positions taken in this article, it is necessary to make some further clarifications. Education for sustainability here refers to a wider perspective that combines environmental education with social justice. In early childhood education, this can, according to Davis (2010, p. 28), be viewed as the need for a process to create »cultures of sustainability« that build 
or transform thinking, practices and relationships. From this standpoint, this text rests on critical research in which preschools and early childhood education are viewed as sites for expressing ethics, politics and policies (Dahlberg \& Moss, 2003; Qvortrup, 2008) since they are venues in a specific social sphere between the official and the private (Fraser, 2009; Habermas, 1998). In these places, childhood and children (James \& James, 2004), children's rights, competence, participation and activism (Davis, 2010) are respected, and environmental ethical values (Wolff, 2011) as well as the idea of democracy as opportunities for recognition and rights (Fraser, 2003, 2009) are constructed and negotiated.

\section{Education for sustainability in Swedish early childhood education}

Swedish preschools have a long tradition of working with nature and environmental issues (Halldén, 2009, 2011; Sandell \& Öhman, 2010; ÄrlemalmHagsér, 2008) as well as valuing social and economic efforts to make the world a better place (Dahlbeck, 2012; Dahlbeck \& Tallberg Broman, 2011).

In Sweden, the Ministry of Education and Science is responsible for the educational system, from preschool to university. Swedish preschools are available for children from one to five years of age, and $83 \%$ of all children in Sweden attend them (The Swedish National Agency for Education, 2011a). All Swedish childcare settings are called "preschools «. In 1998, the Swedish preschool was given a national curriculum. The Swedish National Curriculum for the Preschool (The Swedish National Agency for Education, 2011b) should be seen as a framework and guidelines for work in early childhood settings. The overall national goals are clearly set out both in the Education Act (by the Parliament) and in the Curriculum (by the Government). Democracy is described as a fundamental value and as the foundation for all activities.

The educational principles are built on care and education with play, learning and development operating hand in hand. Children are described as individuals with competences; i.e. active children with experiences, interest, knowledge and skills that should be the starting-point for everyday activities in early childhood settings. One significant aspect of the Swedish national curriculum is that goals are to »be strived for « and not "goals to achieve».

Preschool staff are responsible for developing an environment in which the children become involved and make their own choices. Another task is to arrange supportive learning processes indoors and outdoors, which are designed to deepen children's knowledge and stimulate their desire for further learning. 
A sense of exploration, curiosity and desire to learn should form the foundation for pedagogical activities. These should be based on the child's experience, interests, needs and views. The flow of the child's thoughts and ideas should be used to create variety in learning (The Swedish National Agency for Education, 2011b, p. 9).

Sustainable development as a concept is not mentioned in the policy context, but an ecological approach is one of the main issues to be implemented in all daily activities in preschool:

Preschool should put great emphasis on issues concerning the environment and nature conservation. An ecological approach and a positive belief in the future should typify the preschool's activities. The preschool should contribute to ensuring children acquire a caring attitude to nature and the environment, and understand that they are a part of nature's recycling process. The preschool should help children understand that daily reality and work can be organised in such a way that it contributes to a better environment, both now and in the future. (The Swedish National Agency for Education, 2011b, p. 7)

It may, therefore, be assumed that educators in Swedish preschools have plenty of knowledge about environmental education and education for sustainability and how to put it into practice in a child-centred approach in preschool settings.

\section{Sustainability from three critical standpoints}

Davis (2010) and Pramling-Samuelsson (2011) called for new ways of learning about sustainability in early childhood education with a focus on participation, communication, problem-solving and critical thinking. As already mentioned, this article therefore focuses on preschools as places where environmental ethical values (Wolff, 2011) as well as the idea of democracy as opportunities for recognition and rights (Fraser, 2003, 2009) are constructed and reconstructed. I shall discuss this in two steps; the first comprises Davis's (2010) three theoretical underpinnings: a broadly-based rights dimension, a child competence dimension and a participatory and activist dimension; the second concerns the relationship between human beings and nature (Kronlid, 2005; Plumwood, 2002). 


\section{A broadly-based rights dimension}

Child participation, in the sense that children should have the right to have their say in matters that concern them, is now an accepted principle in politics and in research. This is the result of a long transitional process both in research and in policy-making (James \& James, 2004; United Nations, 1989). The Swedish Preschool Curriculum states that children's views should influence the learning environment and the planned activities in the early childhood context (The Swedish National Agency for Education, 2011b). The purpose is to give children the opportunity to develop understandings of democracy, to take part in decision-making, and to take responsibility for their own actions and the environment. Taking the child's perspective in an early childhood setting means paying attention to the child's own ways of expressing (meaning and) ideas, and to create daily practices that are in agreement with, consider or respect the child's ways of thinking and communicating (Johansson \& Pramling-Samuelsson, 2003). Nevertheless, various studies show that children have relatively few opportunities to influence everyday preschool practices (Emilson, 2011; Johansson \& Pramling-Samuelsson, 2003; Pramling-Samuelsson \& Sheridan, 2003). According to Manson and Bolzan (2010), children's participation in practice can be expressed in different ways. It refers either to individual participation, in which the starting-point is the individual child's "participation as taking part in ", or to "involvement in decision making", where children's collective voices and actions are considered to be both a value in the form of a democratic right and a pedagogical practice (see also Hart, 1997; PramlingSamuelsson \& Sheridan, 2003; Shier, 2001; Sommer, Pramling-Samuelsson, \& Hundeide, 2011).

\section{A child competence dimension}

To understand the meaning of children as active participants in sustainable change, it is essential to understand how childhood, children's competence and children's autonomy have been constructed over time. It is now widely accepted that childhood is a social construction, and that children are daily affected by the view of adults and society (Qvortrup, 2008). It is also intertwined with social, cultural, economic and political structures (Kjørholt \& Qvortrup, 2012). Childhood sociologists such as Prout (2005) and Lee (2001) have made distinctions between children as »human beings« and as »human becomings«. Lee (2009) has further theorised the being/becoming binary, claiming that both children and adults can be understood as being and becoming, depending 
on the context. In Western societies, the rhetoric concerning children's rights is often heard and aims to challenge hegemonic ideologies that view children as innocent, irrational and pre-political (James \& James, 2004). As mentioned earlier, children's participation and influence have an accepted position in politics and child practices, although they remain contested (Kjørholt, 2005) and can be interpreted as a site of struggling for recognition (Fraser, 2003, 2009; Fitzgerald, Greyham, Smith, \& Taylor, 2010). In relation to sustainability and children's rights, it is my opinion that children already are "affected by environmental decision-making and have a right to be involved in it « (Barratt Hacking, Barratt, \& Scott, 2007, p. 532). This means that they should have the right to have their say about, and influence, the activities and knowledge content within their preschool (Pramling Samuelsson \& Sheridan, 2003).

\section{A participatory and activist dimension}

A cornerstone in the participatory and activist dimension is to recognise children as competent subjects and social actors with rights in society. To develop the skills of active and responsible citizenship, children need opportunities to practice them (Chawla \& Flanders Cushing, 2007). Despite this, Davis (2009) showed in a research overview that (in the previous 12 years) there had been exceedingly few studies in which young children have been recognised as agents of change in connection with sustainability. This might originate from the view that younger children and childhood are not related to activism and politics, as they were previously seen in terms of incompetence and dependence (James \& Prout, 1997). Davis (2008) described preschools where children actively share the process of »making a difference«, while Ritchie, Duhn, Rau and Craw (2010) described how early childhood centres participate in collective endeavours and wider community work, working with aspects of ethics of care, for self, for others and for the planet (Duhn, 2011). Siraj-Blatchford, Smith and Pramling-Samuelsson (2010) collated best practice experiences from young children's actions and learning about social, economic and environmentally sustainable development. Moreover, Mackey's (2012) study on young children's involvement in an environmental curriculum showed children that demonstrate their ability to comprehend concepts and issues of sustainability. Engdahl's and Rabušicovás (2011) research, in which 9142 children aged two to eight years were interviewed, showed that children expressed thoughts and ideas and solutions about the Earth, about human connectedness with nature, as well as about caring for the Earth and promoting a healthy environment. All these studies indicate that very young children are capable of relating to 
sustainability issues in their daily lives and of thinking critically, and view themselves as serious stakeholders concerning the environment and the community.

\section{The relationship between humans and nature}

If young children have the competence to relate to sustainability issues in their daily lives, what knowledge, world views and human and natural values need to be critically reflected on? As Wolff (2011) stated: »Humans shape their relation to nature through their views of themselves, of others, and of the entire planet« (p. 329). One way to discuss the relationship of humans/nature can be to define it with the help of concepts such as anthropocentrism, ecocentrism and biocentrism, based on different intrinsic values of the human and the natural world. Anthropocentrism implies that human beings are the most significant species in the universe and/or the superiority of humans over nature. Biocentrism implies that all forms of life have intrinsic value, while in ecocentrism all forms of ecological ecosystems have intrinsic value (Plumwood, 2002; Sandell, Öhman, \& Östman, 2005). Kahriman-Ozturk, Olgan and Tuncer (2012) explored preschool children's attitudes towards anthropocentrism and ecocentrism and found that children aged five to six appear to have ecocentric attitudes towards environmental issues. In contrast, when the researchers asked the children to clarify their reasons, an anthropocentric point of view was revealed. The researcher in that article emphasised the need for further research about early childhood education teachers and the environmental ethics they follow, a need to which the present article is responding.

The relationship between humans and nature can also be understood from a wide, a narrow or a mixed perspective, according to Kronlid (2005). A wide perspective is rooted in deep ecology (see, for example Naess, 1989) as it emphasises the interrelation between humans and the natural world as part of the entire cosmos. From a narrow perspective, humans are separated from nature as nature has become a resource for human use. From a mixed perspective, human connectedness to nature is positioned together with recognition of humans as both natural and cultural beings (Kronlid, 2005, pp. 202-216). Rephrased from Plumwood (2002, p. 132): »Human knowledge is inevitably rooted in human experience of the world, and humans experience the world differently from other species«. This perspective, as I understand it, is close to Bonnett's (2002) view on sustainability as a »frame of mind «. Although critical questions about the relationship between human being and nature are essential to understand the complexity of sustainability, they are seldom emphasised in early childhood education (Elliott, 2008; Halldén, 2011). 
"An education that challenges sustainability builds on reinventions of basic educational theories and attends to human beings' self-relation, humans' mutual relations, and humans' relation to other parts of nature.« (Wolff, 2011, p. 349)

One pertinent question is whether the pedagogical practice in early childhood education is aiming for real change, where contemporary values, knowledge and injustices are challenged.

\section{Research problem and research questions}

This study focuses on how preschools describe learning for sustainability in their applications for a Swedish award, administered by the Swedish National Agency for Education. The award, entitled »Diploma of Excellence in Sustainable Development « (Utmärkelsen Skola för Hållbar utveckling), was initiated in the beginning of the new millennium by Swedish National Agency for Education supported by the Swedish government (SKOLFS 2004:20). The aim with the award was to enhance preschools and schools work with education for sustainable development, i.e. environmental, social, economic dimensions of sustainability.

Some of the findings from these research data have already been published (Ärlemalm-Hagsér, 2012). This paper focuses on two research questions: (1) what views regarding the relationship between humans and nature are described in the applications? And (2) in what ways are young children considered to be important and active participants and agents of change within the applications?

\section{Method}

This case study is part of a larger research project examining early childhood education and education for sustainability in Swedish preschools. The data comprised sixty-four applications made by preschools in 2008 and 2009 to obtain a Diploma of Excellence in Sustainable Development, collated 2009 from the Swedish National Agency for Education. A systematic and strategic selection process was applied to select data for analysis (Denzin \& Lincoln, 2005).

All sixty-four applications were read several times in the initial phase, with a focus on what knowledge content the preschool staff connected to children's learning in relation to education for sustainability.

After the first readings, thirty-four applications were excluded, because twenty-three applications had desist, nine were incomplete and in two 
applications preschools and schools had applied jointly, and this made it difficult to distinguish the preschool-specific content from the school.

In the next step, nine applications were excluded, because their texts mainly described the organisation of work or focused on preschool staff and did not describe what children would do or learn in the preschool. Finally, three applications that mostly cited the Swedish preschool curriculum were excluded. A total of eighteen applications were retained as the basis for the first analysis (Ärlemalm-Hagsér, 2012). In summary, the criteria for data selection can be described as follows:

- $\quad$ Complete applications, i.e. all questions were answered in the application.

- $\quad$ Applications received in 2008 or 2009.

- Applications include descriptions of knowledge content with a focus on children's learning, participation or participation and agency in connection to education for sustainability.

\section{Analysis process}

In the first study, a qualitative content analysis inspired by Granheim and Lundman (2004) was used. The analysis in the first study revealed two different themes of education for sustainability within the written application, a) preschoolers' sense of self and others, b) pre-schoolers' relationships with place, technologies and materials (see Table 1). Within these themes, nine knowledge content areas relevant to education for sustainability were identified. In a next step, these nine knowledge content areas were analysed with the conceptual tools chosen: participation and agency, and an affirmative and transformative approach (Fraser, 2003, 2009; Habermas, 1998). 
Table 1. Overview of findings in the first part of the research project »Education for sustainability« in the Swedish preschool (Ärlemalm-Hagsér, 2012).

\begin{tabular}{|c|c|c|c|c|c|}
\hline \multicolumn{6}{|c|}{ A. Preschoolers' sense of self and others } \\
\hline $\begin{array}{l}\text { The } \\
\text { knowledge } \\
\text { Content } \\
\text { areas }\end{array}$ & $\begin{array}{l}\text { A1 } \\
\text { Children's } \\
\text { Influence } \\
\text { - everyone } \\
\text { should have } \\
\text { their say and } \\
\text { influence }\end{array}$ & $\begin{array}{l}\text { A2 } \\
\text { Health and } \\
\text { Wellbeing } \\
\text { - to take } \\
\text { care of their } \\
\text { health and } \\
\text { well being }\end{array}$ & $\begin{array}{l}\text { A3 } \\
\text { Cultural } \\
\text { Diversity } \\
\text { - expand } \\
\text { and enhance } \\
\text { understand- } \\
\text { ing among } \\
\text { children } \\
\text { of other } \\
\text { cultures and } \\
\text { approaches }\end{array}$ & $\begin{array}{l}\text { A4 } \\
\text { Gender } \\
\text { Equality } \\
\text { - reinforcing } \\
\text { children's } \\
\text { possibilities } \\
\text { of expanding } \\
\text { their gender } \\
\text { roles }\end{array}$ & $\begin{array}{l}\text { A5 } \\
\text { Social skills } \\
\text { - to be kind } \\
\text { to each other }\end{array}$ \\
\hline $\begin{array}{l}\text { The child's } \\
\text { participant } \\
\text { perspective }\end{array}$ & $\begin{array}{l}\text { Participat- } \\
\text { ing as } \\
\text { involvement } \\
\text { in decision } \\
\text { making }\end{array}$ & $\begin{array}{l}\text { Mainly } \\
\text { participation } \\
\text { as »taking } \\
\text { part in«, to } \\
\text { some extent } \\
\text { involvement }\end{array}$ & $\begin{array}{l}\text { Participation } \\
\text { as »taking } \\
\text { part in« }\end{array}$ & $\begin{array}{l}\text { Participation } \\
\text { as »taking } \\
\text { part in« }\end{array}$ & $\begin{array}{l}\text { Mainly } \\
\text { participation } \\
\text { as »taking } \\
\text { part in«, to } \\
\text { some extent } \\
\text { involvement }\end{array}$ \\
\hline $\begin{array}{l}\text { The perspec- } \\
\text { tive } \\
\text { »children as } \\
\text { agents for } \\
\text { change» }\end{array}$ & $\begin{array}{l}\text { Agents for } \\
\text { change in } \\
\text { relation to: } \\
\text { individual } \\
\text { interest, } \\
\text { development } \\
\text { and learn- } \\
\text { ing and to } \\
\text { changes in } \\
\text { the institu- } \\
\text { tion }\end{array}$ & $\begin{array}{l}\text { In relation } \\
\text { to individual } \\
\text { development } \\
\text { and learning } \\
\text { and influ- } \\
\text { ences on the } \\
\text { families }\end{array}$ & $\begin{array}{l}\text { Lack of } \\
\text { child-initiat- } \\
\text { ed actions in } \\
\text { the descrip- } \\
\text { tions }\end{array}$ & $\begin{array}{l}\text { Lack of } \\
\text { child-initiat- } \\
\text { ed actions in } \\
\text { the descrip- } \\
\text { tions }\end{array}$ & $\begin{array}{l}\text { In relation } \\
\text { to individual } \\
\text { interest, } \\
\text { development } \\
\text { and learning. } \\
\text { In relation to } \\
\text { peers and to } \\
\text { changes in } \\
\text { the institu- } \\
\text { tion }\end{array}$ \\
\hline
\end{tabular}

\begin{tabular}{|c|c|c|c|c|}
\hline \multicolumn{5}{|c|}{ B. Preschoolers' relationships with place, technologies and materials } \\
\hline $\begin{array}{l}\text { The knowledge } \\
\text { content areas }\end{array}$ & $\begin{array}{l}\text { B1 } \\
\text { The importance } \\
\text { of a physical } \\
\text { and close rela- } \\
\text { tionship with } \\
\text { nature }\end{array}$ & $\begin{array}{l}\text { B2 } \\
\text { Knowledge of } \\
\text { and respect for } \\
\text { nature - be- } \\
\text { coming aware } \\
\text { ofhow it all fits } \\
\text { together }\end{array}$ & $\begin{array}{l}\text { B3 } \\
\text { Knowledge of } \\
\text { garbage man- } \\
\text { agement and to } \\
\text { take responsi- } \\
\text { bility for their } \\
\text { environment }\end{array}$ & $\begin{array}{l}\text { B4 } \\
\text { Reuse and be } \\
\text { gentle with ma- } \\
\text { terial - how to } \\
\text { be careful with } \\
\text { materials }\end{array}$ \\
\hline $\begin{array}{l}\text { The child's } \\
\text { participant } \\
\text { perspective }\end{array}$ & $\begin{array}{l}\text { Participation as } \\
\text { »taking part in« }\end{array}$ & $\begin{array}{l}\text { Participation as } \\
\text { »taking part in« }\end{array}$ & $\begin{array}{l}\text { Participation as } \\
\text { »taking part in« }\end{array}$ & $\begin{array}{l}\text { Participation as } \\
\text { »taking part in« }\end{array}$ \\
\hline $\begin{array}{l}\text { The perspec- } \\
\text { tive »children } \\
\text { as agents for } \\
\text { change» }\end{array}$ & $\begin{array}{l}\text { Agents for } \\
\text { change in } \\
\text { relation to: indi- } \\
\text { vidual interests, } \\
\text { development nd } \\
\text { learning }\end{array}$ & $\begin{array}{l}\text { In relation } \\
\text { to individual } \\
\text { interests, de- } \\
\text { velopment and } \\
\text { learning }\end{array}$ & $\begin{array}{l}\text { In relation to } \\
\text { individual de- } \\
\text { velopment and } \\
\text { learning and } \\
\text { influences on } \\
\text { families and on } \\
\text { the neighbor- } \\
\text { hood }\end{array}$ & $\begin{array}{l}\text { Lack of child- } \\
\text { initiated actions } \\
\text { in the descrip- } \\
\text { tions }\end{array}$ \\
\hline
\end{tabular}


In the second phase of this study, the focus lies on the views of nature and children's participation, inspired by two types of knowledge content: B1) the importance of a physical and close relationship with nature and knowledge of nature and $\mathrm{B}_{2}$ ) respect for nature, i.e. becoming aware of how it all fits together. In this re-analysis, a total of twenty-one applications, eighteen from the first selection and an additional two applications were selected by intentional sample i.e. preschools that wrote about the relationship between humans and nature.

Stake (2005) described case studies as occurring when a researcher explores a program, an activity, a process or individual/individuals in depth. In this study, the "case « was applications for the Swedish award Diploma of Excellence in Sustainable Development, which was used to investigate education for sustainability. The process implied at first that all statements about the human-nature relationship were identified in the written applications. Second, the qualitative content analysis was, in a further step, deepened with the theoretical analysis tools chosen (Denzin \& Lincoln, 2005). All statements were analysed from the wide, narrow and mixed conceptual perspectives described earlier (Kronlid, 2005; Plumwood, 2002) and according to the ways in which young children were described as active participants and agents of change (Davis, 2010; Fraser, 2003, 2009).

\section{Findings}

The presentation of the findings is disposed as follows: (a) The connectedness with nature and care and respect for nature, (b) Becoming aware of how it all fits together and, (c) Child participation and agency as »taking part in «. The overall results are discussed in the discussion and implications for teaching.

\section{The connectedness with nature and care and respect for nature}

In all applications, outdoor activities are described as an important part of the daily routine in the preschools concerned. Outdoors may refer to the preschool playground or to a "pristine" natural area, e.g. a wood close to the preschool. When they visit the wood, the children are supposed to develop a relationship with nature, a relationship that is established and developed when they experience it through their bodies and their senses. Outdoor play and the connection with the natural world are described as having positive effects on children's future health and environmental awareness:

To give children experiences of nature and maybe contribute to a feeling that they are a part of something bigger... Thanks to our outdoor 
practices, children long to be outdoors, and we hope this will encourage a future interest in environmental issues. (Preschool 10)

Our approach is based on enhancing children's awareness of our way of living and being together can be adapted to create sustainable development... and how we together can take care of nature and the environment and what effects this will give us in the future. (Preschool 13)

Connectedness with nature and care for the natural world are themes that appear frequently in the texts. The connectedness can be interpreted as children's bodily interactions with nature and the natural elements. Here, nature can be understood as an object that can be experienced by the child, and this closeness to nature may be seen as a way to guarantee that they will lead good and healthy lives in the future. Another outlook is the feeling of being »a part of something bigger «. This represents a holistic view of the Earth where children (and adults) are seen as parts of a larger whole, but what this interrelationship consists of is not clarified. Care is often emphasised in the texts, for example, "we should take care of nature». What "care« means in this specific context is not discussed to any great extent. Together, the connectedness with nature and the care of the natural world are interpreted as a mixed view of the humans-nature relationship.

\section{Becoming aware of how it all fits together}

Children are described as being involved in various activities at preschool in order to learn about different aspects of sustainability:

In our preschool, the cycle of nature is a common theme in the daily work. It is a tradition in our preschool to work with nature and our environment. We stay outdoors daily in the playground, we go for walks in the woods and we do other excursions. The children can follow the seasonal changes, make discoveries, experiments, experience and learn about being careful about the different plants and animals. The Right of Public Access is shown in daily and natural contexts. All staff and children are involved in recycling, from the kitchen to the units and the educational work with the children, sorting out garbage, recycling and composting. We are trying to get the kids to understand the cycle of nature by making the children involved and responsible in the work of composting, growing and harvesting crops in our garden. The children follow the entire process. (Preschool 3 ) 
Children and adults get a sense of ecology and the cycles in nature. Which we think is important for everyone and for the willingness to take care of our environment, and also understand how dependent we are on a healthy planet. (Preschool 21)

The children and the teachers in these preschools work regularly with issues connected with learning about the environment and nature. It is learning about natural science as well as practical handling of waste, and gardening. In the excerpts, children and teachers together explore different ways of handling a complex world. The rhetoric is management-influenced, because if children learn about nature and how to handle different problems, such as waste disposal, an understanding of the meaning of sustainability develops automatically. This can be interpreted as an instrumental way of solving the complex problems as it uses ready-made solutions and actions for what a sustainable life can be like.

\section{Child participation and agency as 'taking part in'}

We reflect together with the children on how to take care of nature. (Preschool 4)

Show respect for nature, we talk with the children about how to show respect for nature. (Preschool 6)

In these excerpts, the preschools write that they reflect with the children about how to take care of nature, and in this they then talk about respect for nature, but what this entails is not clear. It seems that respect and care as well as connectedness with nature are themes that are taken for granted but not reflected upon in the pedagogical practice. Here children's voices, actions or initiatives are absent. Children seem to be viewed as passive recipients of knowledge. Children's participation and agency can be understood as »taking part in « and can be related to an individual interest in development and wellbeing. They can be seen as 'becoming' adults with an awareness of environmental issues.

\section{Discussion and implications for teaching}

If we truly take the political commitment to education for sustainability seriously and see education as a vehicle for aiding societies to achieve a sustainable way of living (Agenda 21), we must make critical analyses of the pedagogical practices currently being followed. Beliefs, knowledge and perspectives 
within the everyday dialogues and activities in preschool mould children's meaning-making and understanding about life and the Earth.

The purpose of this article was to analyse how Swedish preschools communicate education for sustainability in written texts. The following aspects were focussed on: (a) the views of human-nature relationships within early childhood education, (b) in what ways young children are considered to be valuable participants and agents of change from these points of view.

In early childhood research, outdoor activities are acknowledged as contributing to wellbeing and development (Elliott, 2010) as well as fostering environmental awareness (Chawla, 1998, 1999; Ewert, Place, \& Sibthorp, 2005; Wilson, 1997). In Swedish preschools, outdoor activities are part of the everyday routines and have been since they started in the mid-18oos, inspired by Rousseau and Fröbel. However, it is apparent that the human-nature relationship is seldom questioned in early childhood education (Elliott, 2008; Halldén, 2011). The texts examined in this study show that this relationship can be interpreted as a mixed one (Kronlid, 2005; Plumwood, 2002) with the view of human connectedness with nature and the urge to take care of and respect nature (compare with Kahriman-Ozturk, Olgan, \& Tuncer, 2012). These perspectives seemed to be taken for granted as they were not explained or clarified in the texts. In each of these perspectives lies the philosophical and ethical assumption of the relationship between humans, nature and the Earth, views that need to be further scrutinised in early childhood education from both theoretical and practical points of view.

In the written texts, children are described as taking part in different activities in the pedagogical practice. These include science education ecology, the cycle of nature, seasonal changes, plants and animals, as well as waste disposal, recycling and gardening. It is obvious that the preschools are following the environment and nature goals in the National Curriculum (The Swedish National Agency for Education, 2011b), but in these descriptions the children's voices are silent even though words such as »reflect» and »talk about» are mentioned in the texts. In the Swedish preschool curriculum (The Swedish National Agency for Education, 2011b), children's right to express their views and influence the daily practice is heavily stressed. So how is it that these children's voices were not of interest within the issues about the relationship between human beings and nature? This question cannot be answered on the basis of this limited empirical material; I can merely refer to earlier researchers that have shown that child participation does not occur so easily (Emilson, 2011; Johansson \& Pramling-Samuelsson, 2003; Pramling-Samuelsson \& Sheridan, 2003). Children and participation still seem to be struggling for recognition (Fraser, 2003, 2009; Fritzgerald, Greyham, Smith, \& Taylor, 2010). 
This study shows that children take part in activities considered to be education for sustainability in the Swedish preschool. Pedagogical approaches like these are argued to be crucial parts of education and sustainability (Davis, 2010; Pramling-Samuelsson, 2011), as well as creating processes for »cultures of sustainability « that build or transform thinking, practices and relationships (Davis, 2010). However, the underlying pedagogy, participation, communication, problem-solving and critical thinking are still not acknowledged in the written text to any great extent.

This can give some implications for teaching as this shed light on and brought detail to general problems of understanding being taken for granted and institutional practices.

In this article, I have sought to argue for the need for a critical discussion about education for sustainability in early childhood education. As respect for nature is considered to be a recipe for developing environmental awareness in preschool, my question is (again): how is it that these critical issues about the relationship between humans and nature are ignored in early childhood education? Is it the age of the child or/and are the pedagogical contents taken for granted?

There is no political vacuum and children in the world are affected by environmental problems and inequalities (Davis, 2011), as well as bearing the consequences of political decisions that are currently being made or not made. Education for sustainability in pedagogical practice needs to be challenged, and one way is to acknowledge children's thoughts, ideas and initiatives and to create opportunities for shared critical thinking. I conclude this article with some words from Elliott (2010): »There is no single experience in nature that creates a sustainability frame of mind, but many over time, crucially beginning in early childhood « (p. 69).

\section{Acknowledgment}

This work present in this research was supported by funding's for the research school »Childhood, learning and didactics« from wthe Swedish Research Council, 721-2007-3671.

\section{Reference}

Agenda 21. (1992). Agenda 21 - Table of Contents. UN Department of Economic and Social Affairs. Division for Sustainable Development. Retrieved from http://www.un.org/esa/sustdev/documents/ agenda21/english/agenda21toc.htm 
Ärlemalm-Hagsér, E. (2008). Skogen som pedagogisk praktik ur ett genusperspektiv. In A. Sandberg (Ed.), Miljöer för lek, lärande och samspel [Environments for play, learning and communication] (pp. 107-136). Lund: Studentlitteratur.

Ärlemalm-Hagsér, E. (2012). Lärande för hållbar utveckling i förskolan - Kunskapsinnehåll, delaktighet och aktörskap kommunicerat i text [Education for Sustainable Development Knowledge content, Participation and Agency]. Nordisk barnehageforskning, 5(2), 1-21.

Hacking, E., Barratt, R., \& Scott, W. (2007). Engaging children: research issues around participation and environmental learning. Environmental Education Research, 13(4), 529-544.

Bonnett, M. (2002). Education for Sustainability as a Frame of Mind. Environmental Education Research, 8(1), 9-20.

Chawla, L. (1998). Significant Life Experiences Revisited: A Review of Research on Sources of Environmental Sensitivity. The Journal of Environmental Education, 29(3), 11-21.

Chawla, L. (1999). Life paths Into Effective Environmental Action. The Journal of Environmental Education, 31(1), 15-26.

Chawla, L., \& Flanders Cushing, D. (2007). Education for strategic environmental behaviour. Environmental Education Research, 13(4), 437-452.

Dahlbeck, J., \& Tallberg Broman, I. (2011). Ett bättre samhälle genom pedagogik: högre värden och barnet som budbärare [A better society through education: values and the child as a messenger]. In P. Williams \& S. Sheridan (Eds.), Barns lärande i ett livslångt perspektiv (pp. 202-214). Stockholm: Liber.

Dahlberg, G., \& Moss, P. (2005). Ethics and politics in early childhood education. London: RoutledgeFalmer.

Davis, J. (2008). What might education for sustainability look like in early childhood? A case for participatory, whole-of-setting approaches. In I. Pramling-Samuelsson \& Y. Kaga (Eds.), The contribution of early childhood education to a sustainable society (pp. 18-24). UNESCO Report. Paris: France.

Davis, J. (2009). Revealing the research 'hole' of early childhood education for sustainability: A preliminary survey of the literature. Environmental Education Research, 15(2), 227-241.

Davis, J. (Ed.) (2010). Young Children and the Environment Early Education for Sustainability. New York, US: Cambridge University Press.

Davis, J. (2011). Early childhood education: the natural starting point for environmental education. In Green Education an A-Z Guide (pp. 115-117). Los Angles, US: Sage.

Davis, J., \& Elliott, S. (2003). Early childhood environmental education: Making it mainstream.

Canberra: Early Childhood Australia.

Denzin, N. K., \& Lincoln, Y. S. (Eds.) (2005). The Sage Handbook of Qualitative Research ( $3^{\text {rd }}$ ed.).

London: Sage Publications.

Duhn, I. (2012). Making 'place' for ecological sustainability in early childhood education,

Environmental Education Research, 18(1), 19-29.

Elliott, S. (Ed.) (2008). The Outdoor Playspace: Naturally. Sydney: Pademelon Press. 
Elliott, S. (2010). Children in the natural world. In J. Davis (Ed.), Young Children and the Environment Early Education for Sustainability (pp. 43-75). New York, US: Cambridge University Press. Emilson, A. (2011). Democracy Learning in a Preschool Context. In N. Pramling \& I. PramlingSamuelsson (Eds.), Educational Encounters: Nordic Studies in Early Childhood (pp. 157-171).

Dordrecht: Springer.

Engdahl, I., \& Rabušicová, M. (2011). Children’s Voices about the State of the Earth. International Journal of Early Childhood, 43(2), 153-176.

Ewert, A., Place, G., \& Sibthorp, J. (2005). Early-Life Outdoor Experiences and an Individual's Environmental Attitudes. Leisure Sciences, 27, 225-239.

Fraser, N. (2003). Social Justice in the Age of Identity Politics: Redistribution, Recognition, and Participation. In N. Fraser \& A. Honneth (Eds.), Redistribution or Recognition? A PoliticalPhilosophical Exchange (pp. 7-109). London: Verso.

Fraser, N. (2009). Scales of Justice: Reimagining political space in a globalizing world. New York: Columbia University Press.

Fritzgerald, R., Greyham, A., Smith, A., \& Taylor, N. (2010). Children's participation as a struggle over recognition: exploring the promise of dialogue. In B. Percy-Smith \& N. Thomas (Eds.), A handbook of children and young people's participation: perspectives from theory and practice (pp. 293-305). London: Routledge.

Graneheim, U. H., \& Lundman, B. (2004). Qualitative content analysis in nursing research: Concepts, procedures and measures to achieve trustworthiness. Nurse Education Today, 24(2), 105-112. Habermas, J. (1998). On the pragmatics of communication. Cambridge, Mass.: MIT Press. Halldén, G. (2009). Naturen som symbol för den goda barndomen [Nature as representation for the good childhood]. Stockholm: Carlsson.

Halldén, G. (Ed.) (2011). Barndomens skogar. Om barn och natur och barns natur [Forests of the childhood. Children and nature and children's nature]. Stockholm: Carlsson.

Hart, R. A. (1997). Children's participation: the theory and practice of involving young citizens in community development and environmental care. London: Earthscan.

Johansson, E., \& Pramling-Samuelsson, I. (2003). Barns perspektiv och barnperspektiv i pedagogisk forskning och praxis [Child Perspectives and Children's Perspectives in Theory and Practice]. Pedagogisk forskning i Sverige, 8(1-2), 1-5. James, A., \& James, A. L. (2004). Constructing Childhood. Theory, Policy and Social practice. New York: Palmgrave Macmillan.

James, A., \& Prout, A. (1997). Constructing and reconstructing childhood ( $2^{\text {nd }}$ ed.) London: RoutledgeFalmer.

Kahriman-Ozturk, D., Olgan, R., \& Tuncer, G. (2012). A Qualitative Study on Turkish Preschool Children's Environmental Attitudes Though Ecocentrism and Anthropocentrism. International Journal of Science Education, 34(4), 629-650.

Kjørholt, T. (2005). The competent child and 'the right to be oneself': reflections on children as fellow citizen in an early childhood center. In A. Clark, A. T. Kjørholt, \& P. Moss (Eds.), Beyond listening: 
children's perspectives on early childhood services (pp. 151-173). Bristol: The Policy Press.

Kjørholt, A. T., \& Qvortrup, J. (Eds.) (2012). The modern child and the flexible labour market: early childhood education and care. Houndmills, Basingstoke Hampshire: Palgrave Macmillan.

Kopnina, H. (2012). Education for sustainable development (ESD): the turn away from 'environment' in environmental education? Environmental Education Research, 18(5), 699-717.

Kronlid, D. (2005). Miljöetik i praktiken: åtta fall ur svensk miljö- och utvecklingshistoria [Practical Environmental Ethics: Eight Cases from Sweden]. Lund: Studentlitteratur.

Lee, N. (2009). Mot en omogen sociologi [Towards an immature sociology]. Lokus: Journal of Research in Childhood and Youth, 21(3-4), 60-79.

Mackey, G. (2012). To know, to decide, to act: the young child's right to participate in action for the environment. Environmental Education Research, 18(4), 473-484.

Manson, J., \& Bolzan, N. et al. (2010). Questioning understandings of children's participation. Applying a cross-cultural lens. In B. Percy-Smith \& N. Thomas (Eds.), A handbook of children and young people's participation: perspectives from theory and practice (pp. 125-132). London: Routledge. Merchant, C. (1994). Naturens död: kvinnan, ekologin och den vetenskapliga revolutionen [The death of nature]. Stockholm: B. Östlings bokförlag. Symposion.

Naess, A. (1989). Ecology, community and lifestyle: Outline of an ecosophy. Cambridge: Cambridge University Press.

Öhman, J. (2011). Theme: New Swedish environmental and sustainability education research.

Education \& Democracy, 2o(1), 3-12.

Plumwood, V. (2002). Environmental Culture. The ecological crisis of reason. New York: Routledge. Pramling-Samuelsson, I. (2011).Why We Should Begin Early with ESD: The role of Early Childhood Education. International Journal of Early Childhood, 43(2), 103-118.

Pramling-Samuelsson, I., \& Sheridan, S. (2003). Delaktighet som värdering och pedagogik.

[Participation as a value and a pedagogical issue]. Pedagogisk forskning $i$ Sverige, 8(1-2), 70-84.

Prout, A. (2005). The future of childhood. London: RoutledgeFarmer.

Qvortrup, J. (2008). Childhood and politics. Educare, 3, 7-19. Retrieved from http://dspace.mah.se/ bitstream/handle/2043/8200/Childhood\%20and\%2opolitics.pdf?sequence=1

Ritchie, J., Duhn, I., Rau, C., \& Craw, J. (2010). Titiro Whakamuri, Hoki Whakamua. We are the future, the present and the past. Caring for self, others and the environment in early years learning.

Wellington: Teaching and Learning Research Initiative.

Sandell, K., \& Öhman, J. (2010). Educational potentials of encounters with nature: reflections from a Swedish outdoor perspective. Environmental Education Research, 16(1), 113-132.

Sandell, K., Öhman, J., \& Östman, L. (2005). Education for Sustainable Development. Nature, School and Democracy. Lund: Studentlitteratur.

Scott, W., \& Gough, S. (2004). Key Issues in Sustainable Development and Learning: A critical review. London and New York: RoutledgeFalmer.

Shier, H. (2001). Pathways to Participation: Openings, Opportunities and Obligations. Children and Society, 15(2), 107-117. 
Siraj-Blatchford, J., Smith, K., \& Pramling-Samuelson, I. (2010). Education for Sustainable Development in the Early Years. Organisation Mondiale Pour l'Education. SKOLFS (2004:20). Förordning om utmärkelsen Skola för hållbar utveckling [Decree concerning the honour: School for Sustainable Development]. Ministry of Education and Science.

Sommer, D., Pramling-Samuelsson, I., \& Hundeide, K. (2011). Barnperspektiv och barnens perspektiv $i$ teori och praktik [Child Perspectives and Children's Perspectives in Theory and Practice]. Stockholm: Liber.

Stake, R. E. (2005).Qualitative Case Studies. In N. K. Denzin \& Y. S. Lincoln (Eds.), The Sage Handbook of Qualitative Research ( $3^{\text {rd }}$ ed.) (pp. 443-466). London: Sage Publications.

The Swedish National Agency for Education. (2011a). National Statics of the Swedish Preschool. Sweden: The Swedish National Agency for Education.

The Swedish National Agency for Education. (2011b). Curriculum for the pre-school, Lpfö 98. Stockholm, Sweden: The Swedish National Agency for Education. Retrieved from http://www. skolverket.se/2.3894/in_english/publications

United Nations (1989). United Nations Convention on the Rights of the Child. Retrieved from http:// www.unicef.org/crc/

Wilson, R. (1997). Environmental Education. A sense of Place. Early Childhood Education Journal, 24(3), 191-194.

Wolff, L-A. (2011). Nature and Sustainability: An Educational Study with Rousseau and Foucault (Doctoral thesis, Åbo Akademi University). Saarbrûcken: LAP Lambert Academic Publishing AG Co KG.

\section{Biographical note}

Eva Ärlemalm-Hagsér is in the final state of her PhD work on Education for Sustainability and young children at the Faculty of Education, Gothenburg University, Sweden. She also works at the teacher education at Mälardalen University. Her background is as a preschool teacher. Main interests are early childhood education with a child oriented approach, focusing on the lived curriculum. In the last years she is focusing on research on outdoor play, learning and gender and education for sustainability. Since 2008 she is convener in the Special Interest Group (SIG) Play and Learning in European Early Childhood Education Research Association (EECERA). 